\title{
Behavioural ontogeny of bearded seals Erignathus barbatus through the first year of life
}

\author{
Charmain D. Hamilton ${ }^{1}$, Christian Lydersen ${ }^{1}$, Mike A. Fedak ${ }^{2}$, Carla Freitas ${ }^{1,5}$, \\ Mark A. Hindell ${ }^{3,4}$, Kit M. Kovacs ${ }^{1, *}$ \\ ${ }^{1}$ Norwegian Polar Institute, Fram Centre, Tromsø 9296, Norway \\ ${ }^{2}$ Scottish Oceans Institute, University of St Andrews, St Andrews, KY16 8LB, United Kingdom \\ ${ }^{3}$ Institute for Marine and Antarctic Studies, University of Tasmania, Hobart, Tasmania 7001, Australia \\ ${ }^{4}$ Antarctic Climate and Ecosystems Cooperative Research Centre, University of Tasmania, Hobart, Tasmania 7000, Australia \\ ${ }^{5}$ Present address: Institute of Marine Research, Flødevigen 4817, Norway
}

\begin{abstract}
Pinniped pups face special ontogenetic challenges as they are born and receive maternal care on solid substrates (land or ice) but must transition to feeding aquatically following weaning. In this study, satellite relay data loggers were used to study behavioural ontogeny of bearded seal Erignathus barbatus pups $(\mathrm{n}=13)$ through their first year in Svalbard, Norway. Pups occupied shallow, coastal habitats and were found in areas with intermediate ice concentrations (in seasons with sea ice: late-autumn/winter). Most pups showed exploratory movement patterns that peaked in the weeks following weaning; maximum home range size occurred at 31 to $60 \mathrm{~d}$ of age. Thereafter, home range size decreased with pups settling into areas along the coast. Time spent diving, dive duration, dive depth and time at the bottom of dives increased during the first weeks of independence, stabilizing when pups were $\sim 50 \mathrm{~d}$ old. Dive depth subsequently decreased to depths comparable to adult bearded seals (by the time pups were $\sim 175 \mathrm{~d}$ old). Record maximum dive depth $(368 \mathrm{~m})$ and duration $(16.5 \mathrm{~min})$ were performed by pups that were 66 and $224 \mathrm{~d}$ old, respectively. Time spent hauled out decreased after weaning, with pups hauling out only sporadically after they were $75 \mathrm{~d}$ old. Bearded seal pups seem to be physiologically and behaviourally well developed by the time they are 2 mo old. Pups did not display the individually specialized diving behaviour seen in adults, which suggests that they continue to fine-tune their aquatic and other life-skills well past the end of the first year of life.
\end{abstract}

KEY WORDS: Diving development $\cdot$ Pinniped development $\cdot$ Phocid seals $\cdot$ Svalbard

\section{INTRODUCTION}

All young mammals have the challenge of acquiring adequate amounts of food for maintenance and growth after the termination of parental care (Bowen 1991, 2018). Pinnipeds have an additional challenge because of the dichotomy of being born on a solid substrate, either land or ice, but having to transition to foraging in an aquatic medium to achieve nutritional independence. This requires development of both physiological abilities (e.g. bradycardia and large

\footnotetext{
*Corresponding author: kit.kovacs@npolar.no
}

body oxygen stores) and behavioural skills (e.g. swimming, diving, etc.) that enable them to find and capture sufficient amounts of food (e.g. Jørgensen et al. 2001, Burns et al. 2005, Folkow et al. 2010, Blanchet et al. 2016). Pups must learn to forage before the protein and energy stores accumulated during nursing are exhausted, despite having limited diving capabilities when they are newly weaned (Bowen 1991, Burns 1999, Burns et al. 2005, Folkow et al. 2010).

The different pinniped families have evolved various strategies in terms of pup development. Otariids

() The authors 2019. Open Access under Creative Commons by Attribution Licence. Use, distribution and reproduction are unrestricted. Authors and original publication must be credited. 
and odobenids have extended periods of maternal care that last from a few months to a few years (see Bowen 1991, 2018, Lydersen 2018, Mann 2018 for more details). Phocid pups have a short, intense nursing strategy; they are weaned at a mass 2 - to 5 -fold their birth mass in periods ranging from a few days to a few weeks (Kovacs \& Lavigne 1986, Bowen 1991, Mann 2018). Lactation duration is linked to the stability of the birthing platform, predation risk and local food availability (e.g. Bowen 1991, Lydersen \& Kovacs 1999). Some phocid pups spend the entire nursing period on a solid substrate, e.g. harp seals Pagophilus groenlandica (Kovacs 1987a), hooded seals Cystophora cristata (Kovacs \& Lavigne 1992), and grey seals Halichoerus grypus (Kovacs 1987b), while others actively swim and dive shortly after birth, while still being nursed, e.g. ringed seals Pusa hispida and bearded seals Erignathus barbatus (Lydersen \& Kovacs 1999), Weddell seals Leptonychotes wedellii (Burns 1999), and harbour seals Phoca vitulina (Jørgensen et al. 2001). Despite early development of diving skills in these latter species, most phocid pups generally do not begin to forage independently until after weaning (Bowen 1991, Lydersen \& Kovacs 1999).

Bearded seals are an Arctic seal with a circumpolar distribution (Kovacs 2018). They inhabit shallow, coastal areas with intermediate to moderate amounts of sea-ice cover (e.g. Gjertz et al. 2000, Simpkins et al. 2003, Cameron et al. 2018). These seals generally avoid areas with heavy sea ice, preferring to remain in areas with broken, drifting ice (Simpkins et al. 2003, Cameron et al. 2018). Bearded seals give birth on free-floating pack ice, the edge of the land-fast ice or on calved pieces of glacier ice when first-year ice is absent (Kovacs et al. 1996, Lydersen et al. 2014). Pupping occurs in April or May with some regional variation in the peak pupping date (McLaren 1958, Burns 1970, Gjertz et al. 2000). Pups weigh $\sim 37 \mathrm{~kg}$ at birth and nurse for between 18 to $24 \mathrm{~d}$ (Gjertz et al. 2000, Kovacs 2018). They receive milk $\sim 3$ times per day and gain $3.3 \mathrm{~kg} \mathrm{~d}^{-1}$ during the nursing period (Lydersen et al. 1996, Krafft et al. 2000). Pups are extremely precocial; they enter the water within a few hours of birth, and during the first weeks of life, they spend $\sim 50 \%$ of the time in the water (Lydersen et al. 1994, Kovacs et al. 1996). Pups are accompanied by their mothers during the first few weeks of life when they are in the water, and by the end of the nursing period, pups are proficient divers that have a body composition similar to adults (Lydersen et al. 1994, 2002, Lydersen \& Kovacs 1999, Gjertz et al. 2000, Watanabe et al. 2009).
Bearded seals have received relatively little research effort despite their circumpolar coastal distribution and their importance as a food source to polar bears Ursus maritimus and as a subsistence resource to Inuit communities. While the nursing period of bearded seals is relatively well studied (i.e. Hammill et al. 1994, Lydersen et al. 1994, 1996, 2002, Holsvik 1998, Krafft et al. 2000, Watanabe et al. 2009), the time after weaning when pups become independent from their mothers has received much less research attention. As the Arctic environment is warming at a faster rate than other areas of the globe and experiencing large decreases in sea ice (Comiso \& Hall 2014, Laidre et al. 2015), knowledge of the behavioural ontogeny of bearded seals is important for successful conservation planning for this species. The purpose of this study was to describe the ontogeny of habitat use, movement patterns, activity and diving behaviour of bearded seals during the first year of life in the High Arctic Archipelago of Svalbard, Norway.

\section{MATERIALS AND METHODS}

\subsection{Capture and instrumentation}

Thirteen bearded seal Erignathus barbatus pups were captured and instrumented in 2005 (07-24 May, $\mathrm{n}=6)$ and 2006 (10-27 May, $\mathrm{n}=7$ ) in the Kongsfjorden/Krossfjorden complex on the west coast of Svalbard $\left(74-81^{\circ} \mathrm{N}, 10-35^{\circ} \mathrm{E}\right.$, Fig. 1, Table 1). Pups were captured on ice floes by hand or taken in the water using a custom-built dip-net (see Hammill et al. 1994, Lydersen et al. 1996 for further details). Pups were then transferred into a restraint net where they were weighed (Salter Spring scales, $\pm 0.5 \mathrm{~kg}$ ) and sex was determined. A satellite relay data logger (SRDL, Sea Mammal Research Unit, University of St Andrews, St Andrews, Scotland) was glued to the hair on their back, slightly behind their shoulders. Captured pups had to have a body mass $\geq 60 \mathrm{~kg}$ for attachment of the SRDL ( $370 \mathrm{~g}$; maximum tag mass/ pup mass ratio of $0.6 \%$ ); a conservative lower body mass was chosen because despite their large size, pups were only a few weeks old when tagged. Pup age was determined by back-calculating their mass at capture to a newborn mass of $37 \mathrm{~kg}$ (Kovacs 2018), assuming a daily mass gain of $3.3 \mathrm{~kg}$ (Lydersen et al. 1996). One pup was initially caught as a newborn so was of known age when the SRDL was attached $12 \mathrm{~d}$ later (F95, Table 1).

SRDLs transmitted data via the Argos satellite system (CLS 2016). Transmitted data included informa- 


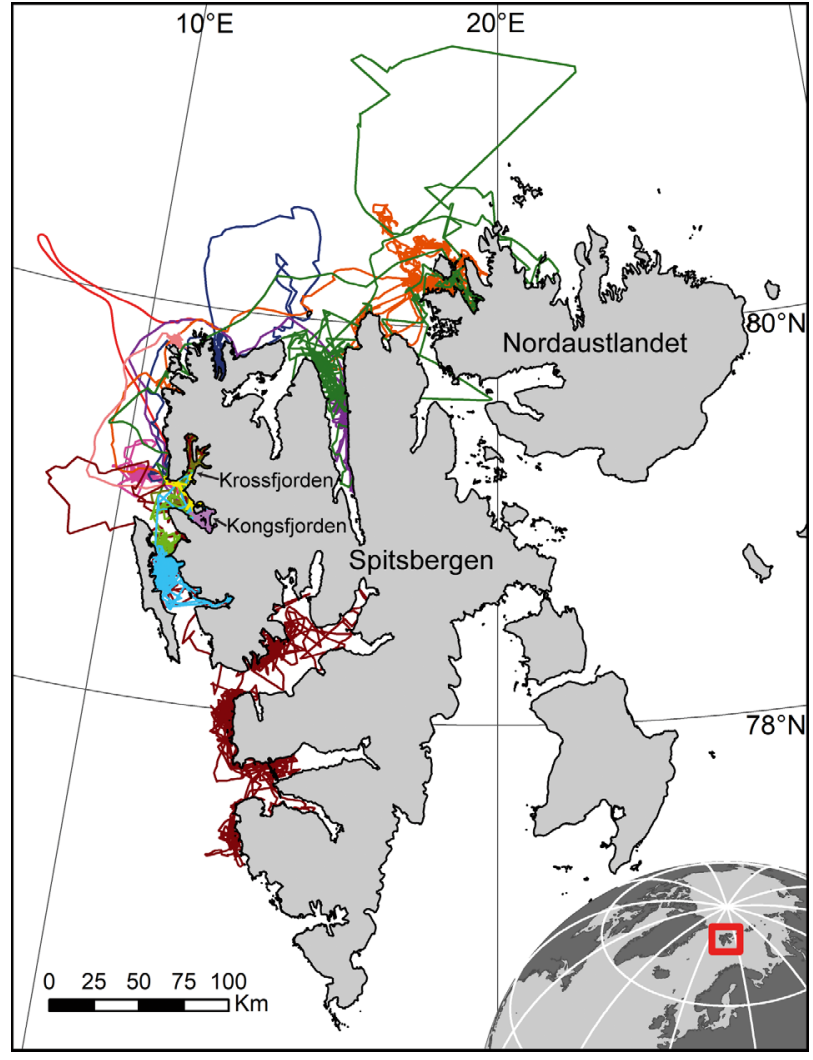

Fig. 1. Tracks of 13 bearded seal Erignathus barbatus pups equipped with satellite relay data loggers in 2005 and 2006 in Svalbard, Norway with major place names specified

tion on activity patterns (e.g. percentage of time spent diving, at the surface of the water column and hauling out in $6 \mathrm{~h}$ intervals), dive behaviour (e.g. dive depth and dive duration), haul-out information (e.g. start and end times for haul-out events) and locations (see www.smru.st-andrews.ac.uk/Instrumentation/ Overview/ for more details).

\subsection{Home range and movement patterns}

All data analyses were conducted in $\mathrm{R}$ version 3.3.3 (R Core Team 2017). Transmitted Argos locations were pre-filtered using the speed-distance-angle (SDA) filter in the argosfilter package using the default settings (Freitas et al. 2008). Obviously erroneous locations (i.e. positions far inland, $\mathrm{n}=132,0.6 \%$ of postSDA filter locations) were removed manually using ArcGIS 10.2 (ESRI, Redlands, CA). Transmitted locations were subsequently filtered using a continuoustime correlated random walk (CTCRW) model with a stopping model incorporated to account for time spent hauled out (crawl package; Johnson et al. 2008). Hourly locations were extracted from the CTCRW models for each seal.

The $95 \%$ home range sizes were calculated for each seal in $30 \mathrm{~d}$ intervals using dynamic Brownian bridge movement models (move package; Kranstauber et al. 2012). This method defines the home range based on animal tracks rather than location points, and allows heterogeneous movement behaviour (see Kranstauber et al. 2012 for more details). Data records $<20 \mathrm{~d}$ in duration for the last month of data transmission were not included in this analysis (see Table 1). Inputs to the home range models included hourly locations, raster cell size of $2.5 \times$ $2.5 \mathrm{~km}$, location error of $1 \mathrm{~km}$, window size of 35 and

Table 1. Information on 13 bearded seal Erignathus barbatus pups equipped with satellite relay data loggers in 2005 and 2006 in Svalbard, Norway. Dates given as year-month-day

\begin{tabular}{|c|c|c|c|c|c|c|c|c|c|c|}
\hline ID & Sex & Stage & Mass & Age (d) & $\begin{array}{l}\text { Tagging } \\
\text { date }\end{array}$ & End date & $\begin{array}{l}\text { Tracking } \\
\text { length (d) }\end{array}$ & $\begin{array}{l}\text { End } \\
\text { age }(d)\end{array}$ & $\begin{array}{c}\text { Track } \\
\text { length }(\mathrm{km})\end{array}$ & $\begin{array}{c}\text { Max distance } \\
\text { from home }(\mathrm{km})\end{array}$ \\
\hline F60 & $\mathrm{F}$ & Pup & 60 & 8 & 2005-05-23 & 2005-06-05 & $13^{\mathrm{a}}$ & 20 & 354 & 191 \\
\hline F95 & $\mathrm{F}$ & Pup & 95 & 12 & $2005-05-23$ & 2005-08-09 & 78 & 90 & 833 & 12 \\
\hline F109 & $\mathrm{F}$ & Pup & 109 & 21 & 2005-05-24 & $2005-12-17$ & 207 & 228 & 2850 & 53 \\
\hline M72 & M & Pup & 72 & 12 & 2005-05-07 & 2005-08-14 & 99 & 111 & 1320 & 54 \\
\hline M93 & M & Pup & 93 & 19 & $2005-05-23$ & 2005-09-08 & 108 & 127 & 1749 & 163 \\
\hline M101 & M & Pup & 101 & 21 & 2005-05-10 & 2005-06-10 & 31 & 52 & 521 & 29 \\
\hline F90 & $\mathrm{F}$ & Pup & 90 & 18 & $2006-05-27$ & $2007-01-24$ & 241 & 260 & 3583 & 190 \\
\hline M66 & M & Weaned & 66 & 20 & 2006-05-25 & $2006-12-12$ & $200^{\mathrm{b}}$ & 221 & 973 & 32 \\
\hline M76 & M & Pup & 76 & 13 & 2006-05-10 & 2006-09-09 & 122 & 135 & 2206 & 123 \\
\hline M77 & $\mathrm{M}$ & Pup & 77 & 16 & 2006-05-19 & $2006-06-27$ & $38^{\mathrm{a}}$ & 56 & 656 & 98 \\
\hline M83 & M & Pup & 83 & 15 & 2006-05-16 & 2006-11-10 & 177 & 193 & 4240 & 324 \\
\hline M92 & M & Pup & 92 & 18 & $2006-05-27$ & 2007-01-14 & 231 & 250 & 3016 & 36 \\
\hline M97 & M & Pup & 97 & 16 & 2006-05-19 & 2007-05-22 & 367 & 384 & 8721 & 192 \\
\hline
\end{tabular}


margin of 9. The maximum distance travelled from the capture site as well as the distance travelled per day were calculated for each seal. The distances calculated represent minimum distances travelled, as pups were assumed to travel in straight lines between points. Linear mixed-effect models (LMMs) that included seal ID as a random effect were used to investigate whether home range sizes and daily distance travelled were influenced by sex (nlme library; Pinheiro et al. 2017). Linear models (LMs) were used to investigate whether maximum distance travelled was influenced by tracking duration or sex. For all models, the response variable (i.e. home range size, daily distance travelled and maximum distance travelled) was included using the identity link, the Gaussian family was used to assess residual variance, and model validation was conducted as recommended by Zuur et al. (2009). Home range size was log-transformed and daily distance travelled was square root-transformed to meet model assumptions.

\subsection{Habitat use}

Time spent in area (TSA) was calculated for each seal with a spatial resolution of $5 \times 5 \mathrm{~km}$ in $3 \mathrm{~d}$ intervals (Sumner 2016) to investigate how habitat use changed during the first year of life. The seals' tracks were divided into $3 \mathrm{~d}$ intervals to resolve seal habitat use with respect to changing environmental variables within an area (e.g. sea-ice concentration). Distance to the nearest tidal glacier front $(\mathrm{km})$, distance to the nearest coastline $(\mathrm{km})$, bathymetric depth $(\mathrm{m})$ and sea-ice concentration (\%) were extracted for the midpoint of each grid cell. Glacier front and coastline shapefiles were obtained from the Norwegian Polar Institute (König et al. 2013, www.npolar.no), and near-daily (daily except for weekends and public holidays) sea-ice concentration shapefiles were obtained from the Norwegian Ice Service (Norwegian Meteorological Institute, https://cryo.met.no). Bathymetric data at $500 \times 500 \mathrm{~m}$ spatial resolution were obtained from the International Bathymetric Chart of the Arctic Ocean Version 3.0 (IBCAO; Jakobsson et al. 2012).

A generalized additive mixed-effect model (GAMM) was run on the TSA values to resolve which environmental variables were important for bearded seal pup habitat use throughout their first year (gam function in the mgcv package; Wood 2006). The response variable (i.e. TSA values) was included with an identity link, and the Gaussian family was used to assess residual variance. TSA values were log-transformed to meet model assumptions. Possible predictor variables included the environmental variables listed above as well as age and sex of the pups. Distance to the nearest tidal glacier front and coast were highly correlated, and thus not included simultaneously in the same model. The environmental variables were included as thin-plate splines in order to characterize non-linear relationships that were discovered during data exploration. Interactions between variables were included as tensor product smooths (i.e. type 'te' smooth term; Wood 2006). Seal ID was included as a random effect by use of the 're' smooth term. Akaike's corrected information criterion was used for model selection and to assess if predictor variables should be included linearly or as smooth terms. Model validation took place as recommended by Zuur et al. (2009). Based on the fitted GAM, pup habitat use was predicted for western and northern Svalbard using monthly sea-ice concentration data from May 2005 until January 2006 and from May 2006 until January 2007.

\subsection{Activity patterns and diving behaviour}

To assess the ontogeny of activity patterns and diving behaviour, the following variables were extracted from the summary and dive records for each seal and day (age): (1) number of hours spent diving (intervals where surface durations between dives $<9 \mathrm{~min})_{i}$ (2) numbers of hours spent at the surface of the water column (begins when time since last dive $\geq 9 \mathrm{~min}$ ); (3) number of hours spent hauled out (wet/ dry sensor dry for $\geq 10 \mathrm{~min}$ ); (4) mean dive duration $(\mathrm{min})_{i}$ (5) mean dive depth $(\mathrm{m})$; (6) maximum dive duration $(\mathrm{min})_{i}(7)$ maximum dive depth $(\mathrm{m})_{i}(8)$ dive frequency (number per $6 \mathrm{~h}$ interval); (9) bottom time (percentage of dives spent at depths $\geq 80 \%$ of the maximum dive depth); (10) percentage of dive in descent; (11) percentage of dive in ascent; (12) surface duration between dives $(s$; intervals between dives < 9 min); (13) haul-out duration (min); and (14) interval between haul-out events (d). Only days that had all 4 (6 h) summary records transmitted were used for the summary variables, with the exception of maximum dive depths and durations. Complete summary data were available for $94.8 \%$ of the tracking days (68-100\% for the different seals); there were no diel or seasonal biases in the occurrence of missing summary data. The overall mean and standard error (for the 13 seals) for each activity and diving variable were calculated as a function of age. Haul-out duration and interval between haul-out events were calculated in $10 \mathrm{~d}$ intervals, due to the low frequency of 
haul-out events. LMMs were used to test for sex differences with respect to the variables listed above, with the exception of maximum dive duration and maximum dive depth. The LMMs were conducted in the same way as the home range model (see above). Dive duration and depth were also compared among 4 age classes (i.e. 30-35, 50-55, 100-105 and 150$155 \mathrm{~d}$ of age) to investigate whether ontogenetic changes occurred in this relationship.

The summary and dive records were used to examine diel patterns (i.e. 00:01-06:00, 06:01-12:00, 12:0118:00 and 18:01-24:00 h) for the variables listed above, with the exception of maximum dive depth, maximum dive duration, haul-out duration and interval between haul-out events. The latter 2 variables were not included due to their irregular occurrence, and because of the long durations of some haul-out events. Diel patterns were investigated using generalized additive models (GAMs; mgcv package, Wood 2006). The dive or summary variables were included as response variables with the identity link, and the Gaussian family was used to assess residual variance. The response variables were transformed as needed to fulfil model assumptions. Hour was included as a predictor variable using a cyclic cubic regression spline (type ' $\mathrm{CC}^{\prime}$ ' smooth curve) to ensure circularity of the variable; a separate hour smooth curve was made for each month by including month as a 'by' variable in the smooth term. Seal id was treated as a random effect by including it as a 're' smooth curve. Model validation took place as recommended by Zuur et al. (2009). Note that in Svalbard, there is no sunset from May through to the end of August and no sunrise from the end of October through February. One seal was tracked for $>12$ mo (M97); the data from May in the second year were not included for this seal.

\section{RESULTS}

The 13 bearded seal Erignathus barbatus pups transmitted data for an average $( \pm 1$ SD) of $147 \pm 102$ d (range: 13-367 d; Fig. 1, Table 1). During this time, 145985 dives (per seal mean \pm SD: $11230 \pm 9080$, range: 848-32382) and 1027 haul-out events (per seal mean \pm SD: $79 \pm 42$, range: $17-164$ ) were transmitted. The maximum dive depth and maximum dive duration were $368 \mathrm{~m}$ and $16.5 \mathrm{~min}$, respectively. Dives were generally shallow and short, with fifty percent of dives being shallower than $37 \mathrm{~m}$ and $<4.5$ min (Fig. 2a,b). The maximum haul-out duration was $33.0 \mathrm{~h}$, while the maximum interval between haul-out events was 72.3 d (pup F90; 17 July to 27 September 2006). Fifty percent of haul-out durations were $<1.9 \mathrm{~h}$ and fifty percent of inter-haulout intervals were $<4.0 \mathrm{~h}$ (Fig. 2c,d).

\subsection{Home range and movement patterns}

Ten of the 13 pups left the Kongsfjorden-Krossfjorden fjord system (their site of birth and capture) and moved along the western and northern coasts of Svalbard (Fig. 1). Pups travelled $2386 \pm 2277 \mathrm{~km}$ (mean \pm SD) over their tracking periods (range: $354-8721 \mathrm{~km}$, median: 1749 km; Table 1). The daily distance travelled $(\mathrm{km})$ increased initially and then stabilized between 10 and $20 \mathrm{~km} \mathrm{~d}^{-1}$ when pups were $\sim 1$ mo old (Fig. 3a). The average maximum distance travelled from the capture site was $115 \pm 92 \mathrm{~km}$ (mean $\pm \mathrm{SD}$, range: $12-324 \mathrm{~km}$, median: $98 \mathrm{~km}$; Table 1). Maximum distance travelled was not related to the duration of the tracking period $(t=0.757, \mathrm{df}=11, \mathrm{p}=0.465)$ or sex of the pup $(t=0.096, \mathrm{df}=11, \mathrm{p}=0.925)$. Sex did not affect the daily distance travelled either (Table 2). Four of the 13 pups undertook offshore trips, to areas where the water was deeper than $500 \mathrm{~m}$, with the deepest water depth being $2304 \mathrm{~m}$ (Fig. 1). The trips by 2 of these pups terminated in areas with drifting offshore pack ice. None of these excursions lasted long; the amount of time spent by each pup in water over $500 \mathrm{~m}$ deep varied between $22 \mathrm{~min}$ and $76 \mathrm{~h}$.

Monthly home range size varied with age; it peaked at $509 \pm 166 \mathrm{~km}^{2}$ (mean $\pm \mathrm{SE}$, median: $234 \mathrm{~km}^{2}$ ) when the pups were 31 to $60 \mathrm{~d}$ old and thereafter declined almost linearly month by month to $146 \pm 30 \mathrm{~km}^{2}$ (mean \pm SE, median: $144 \mathrm{~km}^{2}$ ) when the pups were 6 mo of age (181-210 d old; Fig. 3b). Pup sex did not affect home range size (Table 2 ).

\subsection{Habitat use}

Bearded seal pup habitat use was affected by distance to the coast, bathymetric depth, sea-ice concentration and pup age (Table 3, Table S1 in the Supplement at www.int-res.com/articles/suppl/m627p179_ supp.pdf). Initially pups stayed close to the coast (during spring and summer), but then between September and December, when they were 4 to 6 mo old (120$210 \mathrm{~d})$, they explored areas further offshore before once again becoming more closely affiliated with the Svalbard coastline (Fig. 4, Figs. S1 \& S2). Pups predominately occupied areas shallower than $100 \mathrm{~m}$ (Table 3). During the summer and early fall (June until 

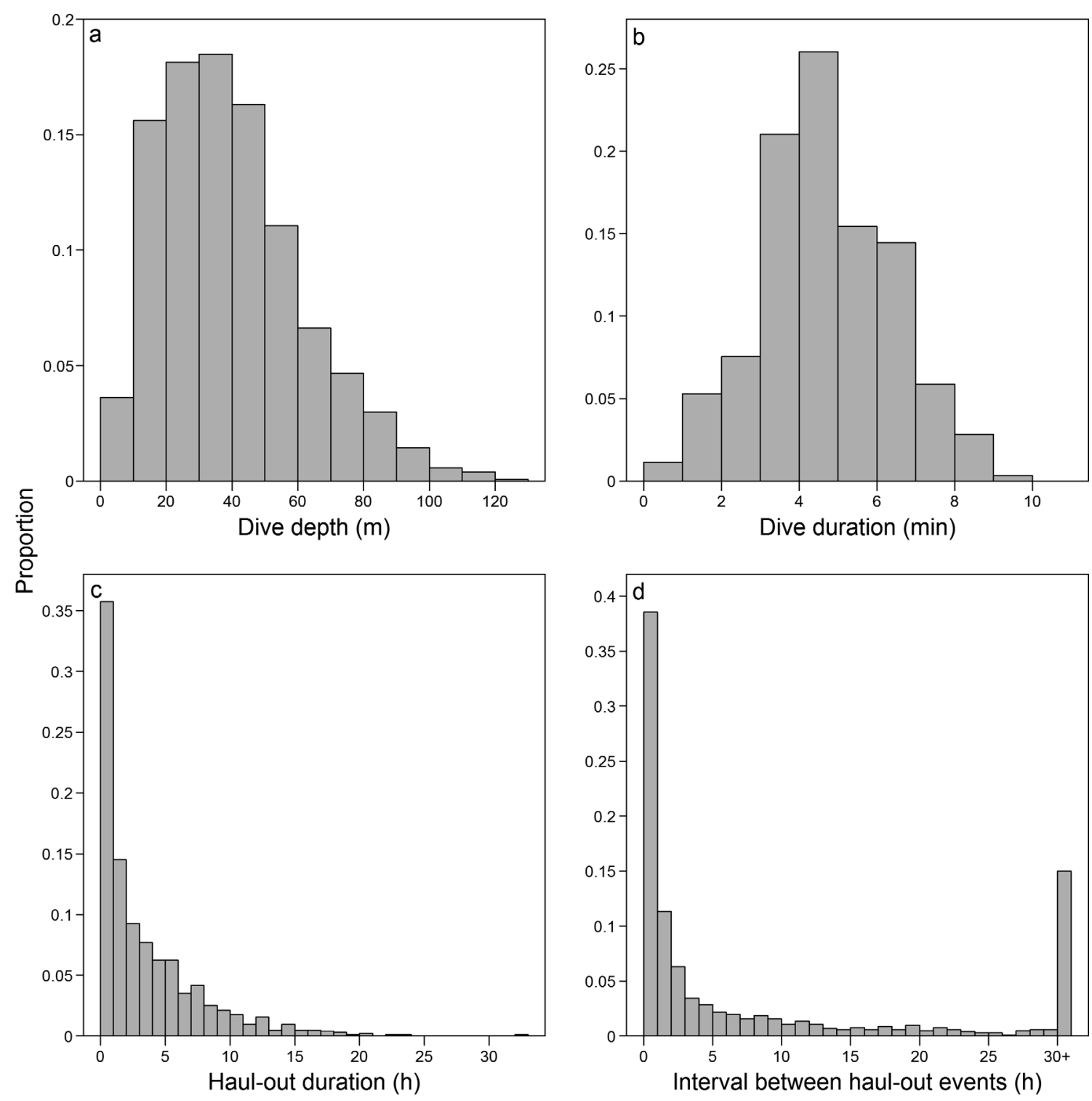

Fig. 2. Proportional distribution of (a) dive depth, (b) dive duration, (c) haul-out duration and (d) interval between haul-out events for 13 bearded seal Erignathus barbatus pups equipped with satellite relay data loggers in 2005 and 2006 in Svalbard, Norway

October), sea-ice concentration had little impact on pup habitat use. However, during late fall and winter (November until February) pups used areas with intermediate sea-ice concentrations $(10-70 \%)$ but avoided areas with heavy sea-ice concentrations (70-100\%; Fig. 4, Figs. S2 \& S3).

\subsection{Activity patterns and diving behaviour}

The amount of time spent diving increased quickly during the first weeks of life from 0.3 to $4 \mathrm{~h} \mathrm{~d}^{-1}$ of diving (9-11 $\mathrm{d}$ old) to 15 to $18 \mathrm{~h}$ of diving per day by the time pups were $60 \mathrm{~d}$ old (Fig. 5a). The amount of time spent at the surface (i.e. intervals between dives $\geq 9 \mathrm{~min}$ ) was more stable. It initially increased to $12 \mathrm{~h} \mathrm{~d}^{-1}$ when pups were $\sim 20 \mathrm{~d}$ old but afterwards decreased to $\sim 7$ to $9 \mathrm{~h} \mathrm{~d}^{-1}$ by the time pups were $30 \mathrm{~d}$ old, remaining at this level for the remainder of the tracking period (Fig. 5b). The amount of time spent hauled out decreased concomitantly with increased time spent diving, with pups hauling out only sporadically after they were $\sim 75 \mathrm{~d}$ old (Fig. 5c). The mean interval between haul-out events increased as pups got older, while the mean haul-out duration showed no general trend over the tracking period (Fig. 6). 

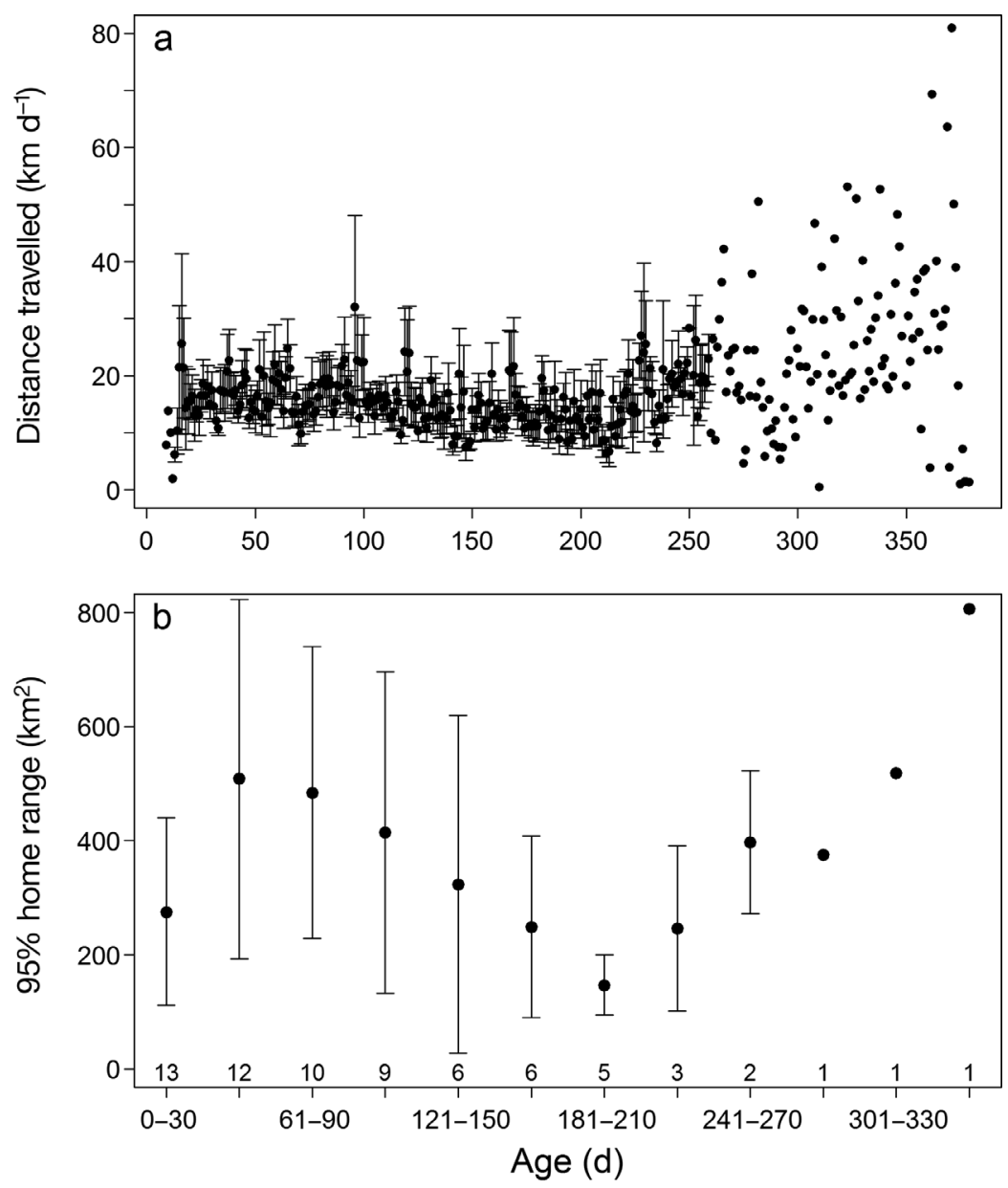
shown when only 1 pup was transmitting data) and (b) $95 \%$ home range size (mean $\pm 95 \%$ CI) over the first year of life for 13 bearded seal Erignathus barbatus pups equipped with satellite relay data loggers in 2005 and 2006 in Svalbard, Norway. The number of pups transmitting data is shown at the bottom of (b)
Fig. 3. Ontogenetic changes in (a) distance travelled (mean $\pm \mathrm{SE}$; no error bars

time pups were $50 \mathrm{~d}$ old. Later, percentage of the dive spent in ascent increased slightly for $\sim 175 \mathrm{~d}$ old pups (Fig. 8b,c). Dive frequency was quite stable throughout the tracking period at 40 to 60 dives $6 \mathrm{~h}^{-1}$ (Fig. 9a). The maximum dive depth (368 $\mathrm{m}$; pup M92) and duration (16.5 min; pup F90) were performed by pups that were 66 and $224 \mathrm{~d}$ old, respectively (Fig. 9b,c).

From June to November, some activity and dive parameters showed diel patterns. The pups generally dove more and spent less time at the surface, had higher dive frequencies, deeper mean dive depths and shorter surface durations between dives in the period from 06:00 until 18:00 h (see Figs. S5-S9), despite most of this period having $24 \mathrm{~h}$ light. The pups also spent a larger proportion of the dive at the bottom, and shorter proportions of the dive in descent and ascent, during these same hours in September and October (see Figs. S10-S12). No diel patterns were found in dive duration or the amount of time spent hauling out (see Figs. S13 \& S14). A similar diel pattern was seen again for M97 during February and March for some parameters (time spent diving, time spent at the surface, mean dive depth and number of dives) after the end of the polar night.

\section{DISCUSSION}

the pups' data records, to 4 to 6 min by the time they were $50 \mathrm{~d}$ old, while surface duration between dives (intervals between dives $<9 \mathrm{~min}$ ) showed only a slight decrease over this time interval (Fig. 7a,b). Mean dive depth also increased progressively to an average of $\sim 50 \mathrm{~m}$ by the time pups were $50 \mathrm{~d}$ of age and subsequently decreased to $\sim 20 \mathrm{~m}$ by the time they were $175 \mathrm{~d}$ old (Fig. $7 \mathrm{c}$ ). Similarly, older pups (>100 d old) had shallower dives for a given dive duration than younger pups (Fig. S4). Time spent at the bottom of dives (as a proportion of total dive time) showed a trend similar to dive depth, with an increase to $60 \%$ by the time pups were $50 \mathrm{~d}$ old and then a decrease to $40-50 \%$ by the time pups were 175 d old (Fig. 8a). Percentages of dive time spent in descent and ascent were initially high, but both decreased to $\sim 15 \%$ and $20-30 \%$, respectively, by the
This is the first study reporting detailed ontogebearded seals Erignathus barbatus throughout their first year of life. Previous studies have shown that pups of this species are extremely precocial, swimming and even diving with their mothers within hours of their birth, and quickly developing aquatic skills further in the first weeks of life (Hammill et al. 1994, Lydersen et al. 1994, 1996, Kovacs et al. 1996, Watanabe et al. 2009). The current study demonstrates that this development continues to occur rapidly during the first month following weaning (also see Gjertz et al. 2000) after which time both dive parameters and general activity patterns stabilize, although even 1 yr old pups have not yet acquired netic patterns in habitat use and behaviour of 
Table 2. Linear mixed model results showing the effect of sex on habitat use, activity and diving variables for 13 bearded seal Erignathus barbatus pups equipped with satellite relay data loggers in 2005 and 2006 in Svalbard, Norway

\begin{tabular}{|c|c|c|c|c|c|}
\hline Response variable & Predictor variables & Estimate & $\mathrm{SE}$ & $t$ & $\mathrm{p}$ \\
\hline \multirow[t]{2}{*}{$\log \left(95 \%\right.$ home range $\left.\left[\mathrm{km}^{2}\right]\right)$} & Intercept & 5.481 & 0.418 & 13.119 & $<0.001$ \\
\hline & sex & -0.082 & 0.497 & -0.165 & 0.872 \\
\hline \multirow[t]{2}{*}{ Sqrt(distance travelled $\left[\mathrm{m} \mathrm{d}^{-1}\right]$ ) } & Intercept & 22.578 & 2.159 & 10.457 & $<0.001$ \\
\hline & sex & -0.170 & 2.593 & -0.065 & 0.949 \\
\hline \multirow[t]{2}{*}{ Log(surface duration $[\mathrm{s}])$} & Intercept & 4.509 & 0.068 & 64.659 & $<0.001$ \\
\hline & sex & -0.058 & 0.082 & -0.725 & 0.494 \\
\hline \multirow[t]{2}{*}{ Bottom time (\%) } & Intercept & 53.185 & 3.686 & 16.698 & $<0.001$ \\
\hline & sex & 1.372 & 4.403 & 0.034 & 0.761 \\
\hline \multirow[t]{2}{*}{ Log(Ascent time [\%]) } & Intercept & 3.188 & 0.080 & 39.778 & $<0.001$ \\
\hline & sex & 0.006 & 0.095 & 0.067 & 0.948 \\
\hline \multirow[t]{2}{*}{ Sqrt(Descent time [\%]) } & Intercept & 4.114 & 0.173 & 23.847 & $<0.001$ \\
\hline & sex & -0.050 & 0.206 & -0.245 & 0.811 \\
\hline \multirow[t]{2}{*}{ Time spent diving $\left(\mathrm{h} \mathrm{d}^{-1}\right)$} & Intercept & 12.851 & 1.166 & 11.023 & $<0.001$ \\
\hline & sex & 1.244 & 1.394 & 0.806 & 0.437 \\
\hline \multirow[t]{2}{*}{ Time spent at the surface $\left(\mathrm{h} \mathrm{d}^{-1}\right)$} & Intercept & 8.071 & 0.618 & 13.065 & $<0.001$ \\
\hline & sex & -0.333 & 0.737 & -0.452 & 0.660 \\
\hline \multirow[t]{2}{*}{ Time spent hauling out $\left(\mathrm{h} \mathrm{d}^{-1}\right)$} & Intercept & 0.880 & 0.159 & 5.549 & $<0.001$ \\
\hline & sex & -0.067 & 0.188 & -0.358 & 0.727 \\
\hline \multirow[t]{2}{*}{ Sqrt(dive duration [min]) } & Intercept & 1.813 & 0.154 & 11.731 & $<0.001$ \\
\hline & sex & 0.243 & 0.185 & 1.315 & 0.215 \\
\hline \multirow[t]{2}{*}{ Diving depth (m) } & Intercept & 32.050 & 5.280 & 6.070 & $<0.001$ \\
\hline & sex & 11.601 & 6.312 & 1.838 & 0.093 \\
\hline \multirow[t]{2}{*}{ Dive frequency (no. $6 \mathrm{~h}^{-1}$ ) } & Intercept & 51.169 & 3.011 & 16.992 & $<0.001$ \\
\hline & sex & -5.521 & 3.598 & -1.534 & 0.153 \\
\hline \multirow[t]{2}{*}{ Log(haul-out duration [min]) } & Intercept & 4.650 & 0.228 & 20.388 & $<0.001$ \\
\hline & sex & 0.105 & 0.273 & 0.385 & 0.708 \\
\hline \multirow[t]{2}{*}{ Log(intervals between haul-out events [min]) } & Intercept & 5.339 & 0.390 & 13.686 & $<0.001$ \\
\hline & sex & 0.296 & 0.467 & 0.633 & 0.539 \\
\hline
\end{tabular}

the highly individualistic foraging patterns seen in adult bearded seals (see Hamilton et al. 2018; 1 yr old pups are 35 to $50 \%$ of the asymptotic mass of adults, Andersen et al. 1999).

Most young mammals display dispersal or exploratory movements when they are first separated from their mothers (Wolff 1994). This is certainly the case for many pinniped species, including bearded

Table 3. Generalized additive model results for the time spent in area analysis for 13 bearded seal Erignathus barbatus pups equipped with satellite relay data loggers in 2005 and 2006 in Svalbard, Norway. The estimate, SE, $t$-value and pvalue for the linear predictor variables and the estimated degrees of freedom (edf), F-value and p-value for the smooth terms are shown, with dashes marking absent values for the linear or smooth terms. 'te' refers to a tensor product smooth term

\begin{tabular}{|lcccrr|}
\hline Predictor variable & Estimate & edf & SE & $t / F$ & $p$ \\
\hline Intercept & 9.787 & - & 0.125 & 78.312 & $<0.001$ \\
Depth (50-100 m) & -0.076 & - & 0.054 & -1.397 & 0.162 \\
Depth (100-200 m) & -0.429 & - & 0.061 & -7.086 & $<0.001$ \\
Depth (>200 m) & -0.382 & - & 0.063 & -6.052 & $<0.001$ \\
te(Dist Coast, Age) & - & 11.662 & - & 15.129 & $<0.001$ \\
te(Ice, Age) & - & 9.474 & - & 2.127 & 0.021 \\
Seal ID & - & 11.338 & - & 27.307 & $<0.001$ \\
\hline
\end{tabular}

seals (Stewart 1997, Gjertz et al. 2000, Raum-Suryan et al. 2004, Blanchet et al. 2016). Gjertz et al. (2000) reported that 1 of 7 bearded seal pups in their study travelled almost to Greenland (from Svalbard) during its tracking period. While none of the pups in this study performed such long-distance movements, 10 of the 13 pups did disperse from their natal fjord shortly after weaning. The 3 remaining pups stayed in the Kongsfjorden-Krossfjorden complex throughout their tracking periods. One of these pups was seen in the area where it had been born the following summer (identified initially by the tag 'print' in the hair and then via its flipper tags; K.M.K. and C.L. pers. obs.). All of the pups in this study initially remained over the coastal shelf, but between the ages of 4 to 6 mo, 4 of the pups travelled into offshore areas. However, they all returned to the coast after relatively short periods.

Distance travelled per day increased around the time of weaning, 


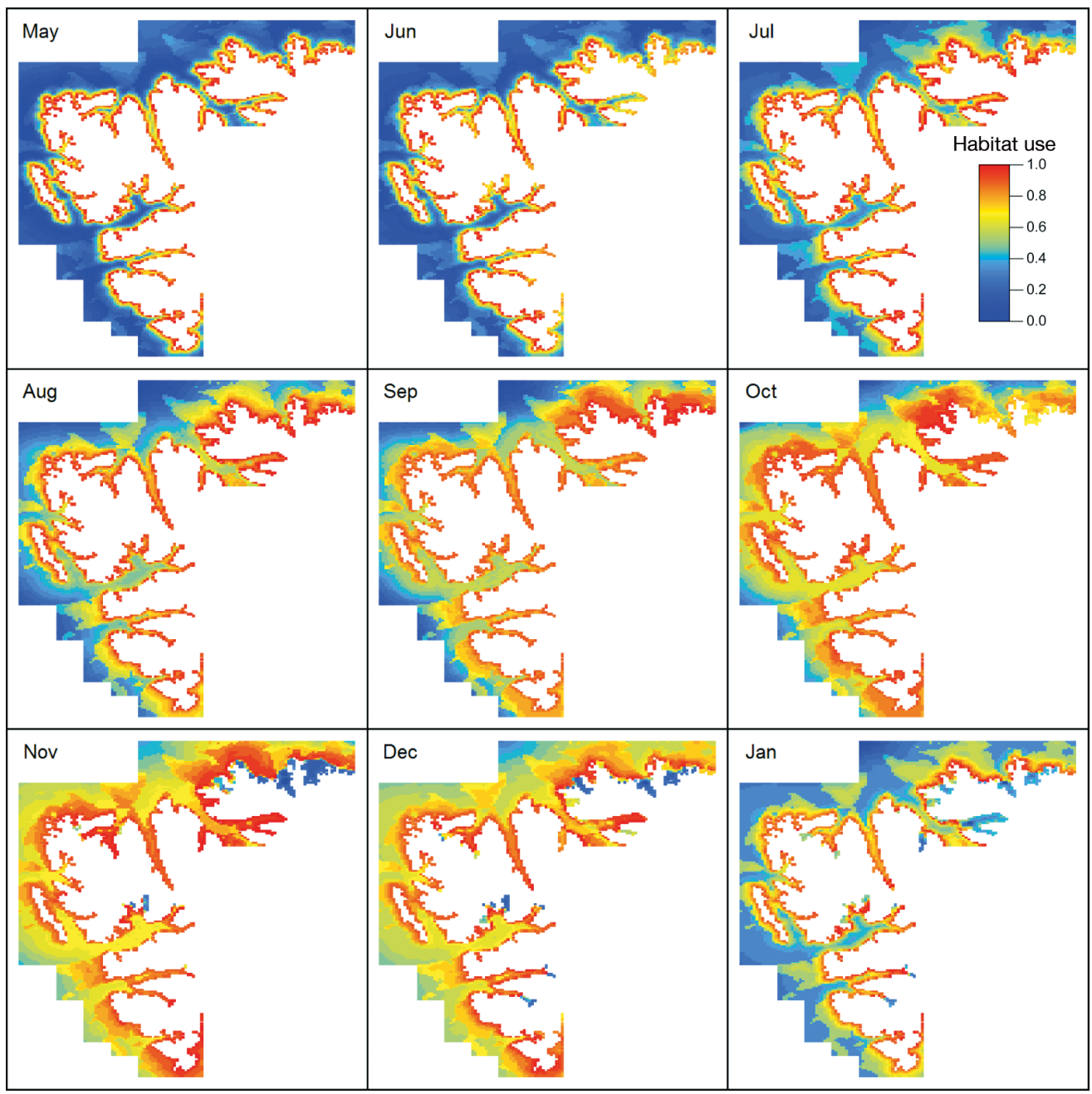

Fig. 4. Predicted habitat use around western and northern Svalbard from May 2005 to January 2006 for 13 bearded seal Erignathus barbatus pups. Values close to 1 indicate areas predicted to be highly used, and values close to zero are predicted to be least used by bearded seal pups. Predicted habitat use for May 2006 to January 2007 is presented in Fig. S2

and home range size peaked early in the period of independence. The average distance travelled per day by pups increased daily until it stabilized at $\sim 20 \mathrm{~km} \mathrm{~d}^{-1}$ approximately a month after weaning. Although average distance travelled per day subsequently remained quite constant, home range size decreased markedly as most of the pups settled into specific areas along the coast, presumably where they found sufficient benthic prey. A couple of the pups did move from area to area sequentially. Two pups moved away from Spitsbergen to Nordaustlandet, a large island in the northeast of the archipelago, while another moved southward along the west coast of Spitsbergen. Both distance travelled per day and home range size increased somewhat in late winter/early spring of the following year, when pups were $\geq 250 \mathrm{~d}$ of age, although limited sample sizes late in the tracking period warrant caution in interpreting patterns.

Pups are particularly vulnerable in the first weeks of independence when they must transition to feeding themselves (exclusively) and avoiding predators without their mothers' vigilance. Two of the 13 pups in this study were killed by polar bears in the northwest corner of Spitsbergen (pups F69 and M77; Table 1) in the first weeks of dispersal from their natal areas. These were confirmed kills, as the sites were visited when the tags began signalling from shore-based locations. It is likely that short tracking durations for some additional pups terminated in the same manner (e.g. M101; Table 1). The transition from nursing to self-feeding is likely less abrupt for bearded seals than for many of the other ice-breeding pinniped species. There is some evidence (milk 


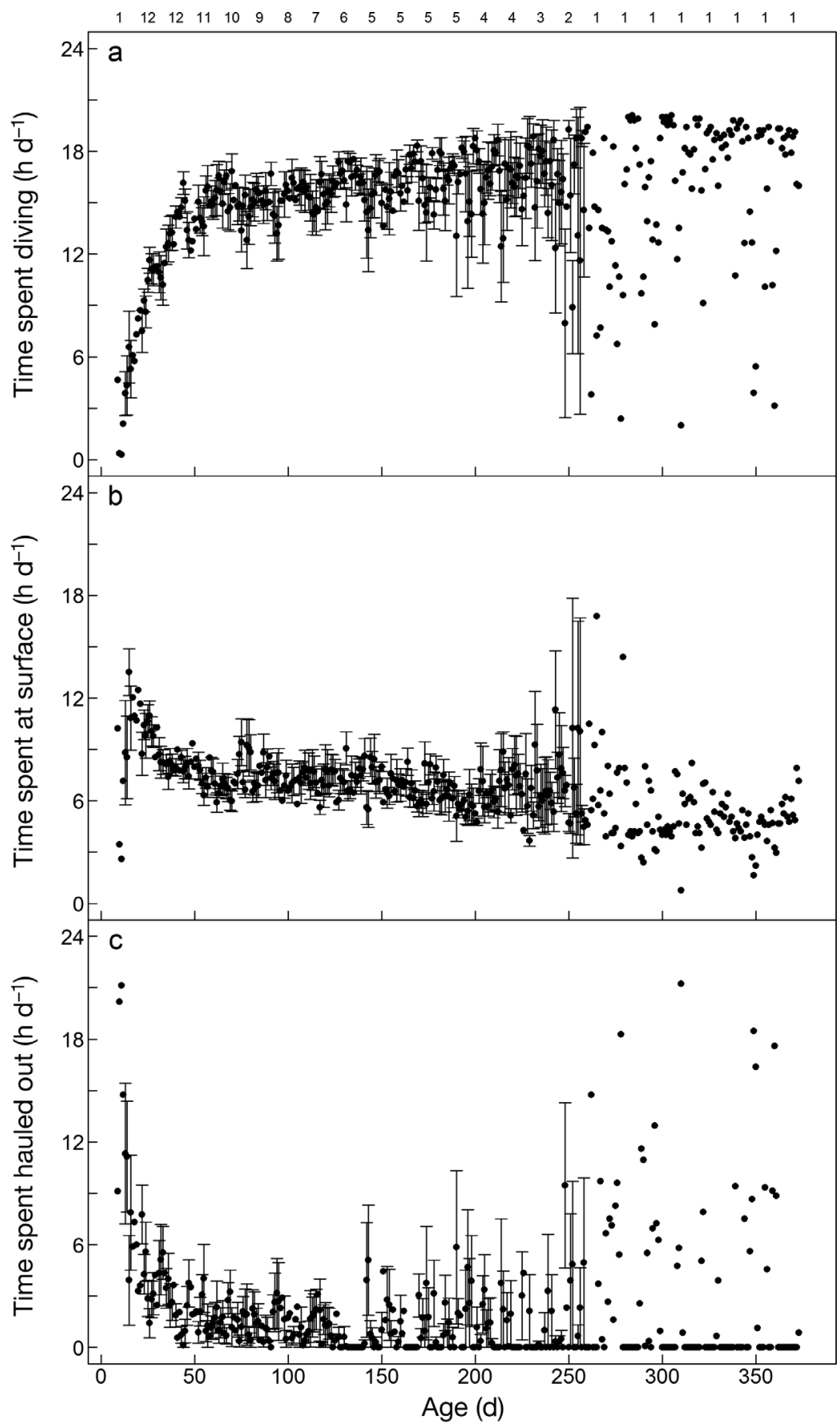

Fig. 5. Ontogenetic changes in (a) time spent diving, (b) at the surface and (c) hauled out (mean $\pm \mathrm{SE}$; no error bars shown when only 1 pup was transmitting data) over the first year of life for 13 bearded seal Erignathus barbatus pups equipped with satellite relay data loggers in 2005 and 2006 in Svalbard, Norway. The number of pups transmitting data is shown above (a) weaning (Lydersen \& Kovacs 1999, Gjertz et al. 2000, Krafft et al. 2000).

Water depth $(<100 \mathrm{~m})$ and proximity to the coast largely defined the habitat chosen by the bearded seal pups in this study. Sea-ice concentration did not play an important role in summer and early fall, but modest sea-ice concentrations $(10-70 \%)$ were an important habitat characteristic during late fall and winter. Svalbard's isolated location and its narrow shelf might be defining regional characteristics determining these choices by this benthic-feeding seal species. Bearded seals of all ages are quite sedentary in Svalbard, largely remaining in shallow, coastal areas (this study, Gjertz et al. 2000, Krafft et al. 2000, Hamilton et al. 2018). Similar to the pups in this study, adults were found in coastal areas with low sea-ice concentrations ("10\%) in the summer and early autumn, and preferred intermediate sea-ice concentrations (10$70 \%$ ) in the late-autumn and winter, according to Hamilton et al. (2018). In contrast, juvenile bearded seals in the Bering Sea move south with the advancing sea ice, selecting areas near the ice edge and occupying areas with moderate to high ice concentrations; adult bearded seals in this same region have a similar migration, though they remain in areas further north than young animals where sea-ice concentrations are heavier (Cameron et al. 2018). These 2 Arctic regions (North Pacific and North Atlantic Arctic seas) where bearded seal tracking have been conducted are quite different in terms of sea-ice patterns and bathymetry. The Bering and Chukchi Seas in the North Pacific region are quite homogeneously shallow and are characterised by a distinct annual cycle of advancing (fall/winter) and retreating (spring/summer) sea ice. In contrast, and solid food simultaneously in the stomach) that at least some bearded seal pups might eat solid food while still nursing (Chapskii 1938). Diving with their mothers certainly affords the possibility that pups might learn foraging skills during the nursing period and also consume some self-caught food prior to
Svalbard has a narrow shelf and a distinct slope-drop that descends to several thousand metres some tens of kilometres to the west and north of Spitsbergen, and sea ice does not consistently extend south of the archipelago in winter (though it did some decades ago). It is interesting to note that ringed seals Pusa hispida 


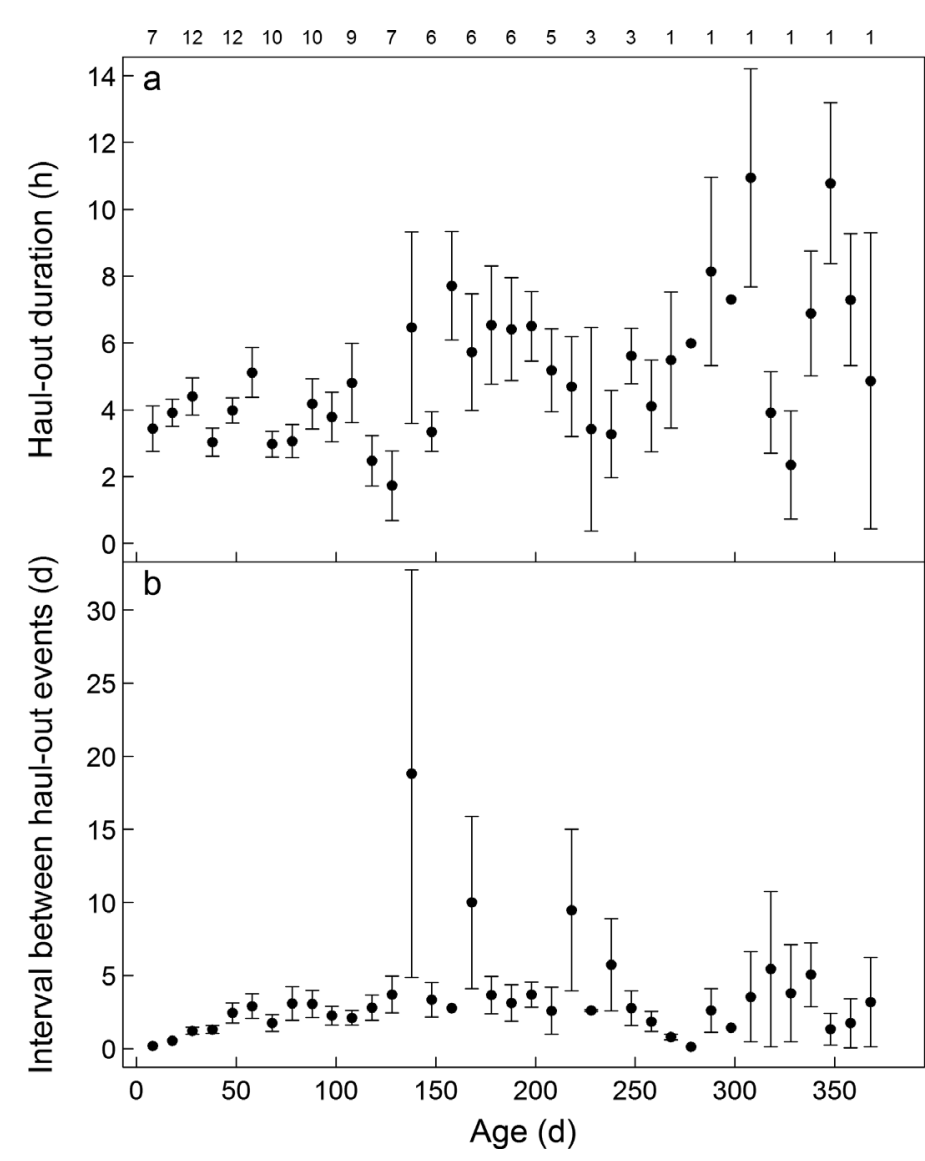

Fig. 6. Ontogenetic changes in (a) haul-out duration and (b) interval between haul-out events over the first year of life for 13 bearded seal Erignathus barbatus pups; no error bars shown when only 1 pup was transmitting data. Data are mean \pm SE. The number of pups transmitting data is shown above (a)

and white whales Delphinapterus leucas also move in association with the advancing and retreating sea ice in the Bering and Chukchi Seas, while these species are more sedentary and coastal in Svalbard (Crawford et al. 2012, Hauser et al. 2014, Hamilton et al. 2016, Vacquié-Garcia et al. 2018).

The unstable nature of the birthing and nursing platforms used by bearded seals, and the risk of predation from polar bears, are likely factors influencing the early swimming and diving behaviour of this species (Lydersen \& Kovacs 1999). Studies have documented that swimming and diving performance increase rapidly in the first weeks of life when pups are accompanied by their mothers (Lydersen et al. 1994, Gjertz et al. 2000, Watanabe et al. 2009). This development continues to accelerate at a remarkably consistent pace up to the time when pups are $\sim 50 \mathrm{~d}$ old ( 1 mo after weaning). This pattern is very similar to what is seen in hooded seals Cystophora cristata and grey seals Halichoerus grypus, which also have rapid aquatic skill development that stabilizes at $\sim 50 \mathrm{~d}$ of age (Bennett et al. 2010, Folkow et al. 2010). Some other phocid seal species, such as harbour seals Phoca vitulina and Weddell seals Leptonychotes weddellii, are more similar to otariids and odobenids, in having their aquatic skills develop over more protracted periods (Burns 1999, Blanchet et al. 2016).

During the first few days of life, bearded seal pups spend most of their time sleeping on the ice, but by the time they are 1 to 2 wk old, they spend more than half of their time in the water (Lydersen et al. 1994). The current study shows that time spent in the water increases steadily until pups are largely aquatic, diving $>15 \mathrm{~h}$ per day and being at the surface of the water for an average of $8 \mathrm{~h}$ per day throughout the summer, fall and winter of their first year of life. Some of the surface time is almost certainly spent sleeping (see Burns \& Frost 1979). However, surface time also facilitates recovering from diving, and given the short durations of most surface periods performed by pups (93 $\pm 5 \mathrm{~s}$, mean $\pm \mathrm{SE}$ ), this function likely dominates the time pups spend at the surface.

Bearded seal pups increased the depth and duration of dives rapidly and steadily in the weeks following tag deployment, similar to other pinniped species that have been studied (e.g. Burns 1999, Pitcher et al. 2005, Blanchet et al. 2016), up until they were $~ 50 \mathrm{~d}$ of age. Dive duration continued to increase at a reduced rate during the autumn, and remained steady throughout the remainder of the deployment period. Dive depth had quite a different progression, with pups decreasing their average $( \pm 1 \mathrm{SE})$ dive depths from the time they were $\sim 50 \mathrm{~d}$ old $(50 \pm 9 \mathrm{~m})$ until they were $\sim 200 \mathrm{~d}$ old $(26 \pm 7 \mathrm{~m})$, undoubtedly in concert with learning where they met with foraging success. Similarly, the maximum dive depth for the deployment period was reached at $\sim 2$ mo of age, although pups close to $1 \mathrm{yr}$ old continued to dive to depths deeper than $300 \mathrm{~m}$. Improved dive performance by bearded seal pups is almost certainly linked to both experience and physiological development, similar to other species of aquatic mammals (see Jørgensen et al. 2001, Burns et al. 2004,).

Weaned pups of many pinniped species compensate for short dive durations by making more dives to foraging depths or spending a greater proportion of time diving compared to adults (Burns 1999, Fowler et al. 2006, Vacquie-Garcia et al. 2017). In contrast, bearded seal pups spent less time diving than adults throughout the tracking period, and dove a similar number of times per day compared to adults from the time of weaning until pups were $\sim 180 \mathrm{~d}$ of age (this study, Hamilton et al. 2018). This is likely because the 


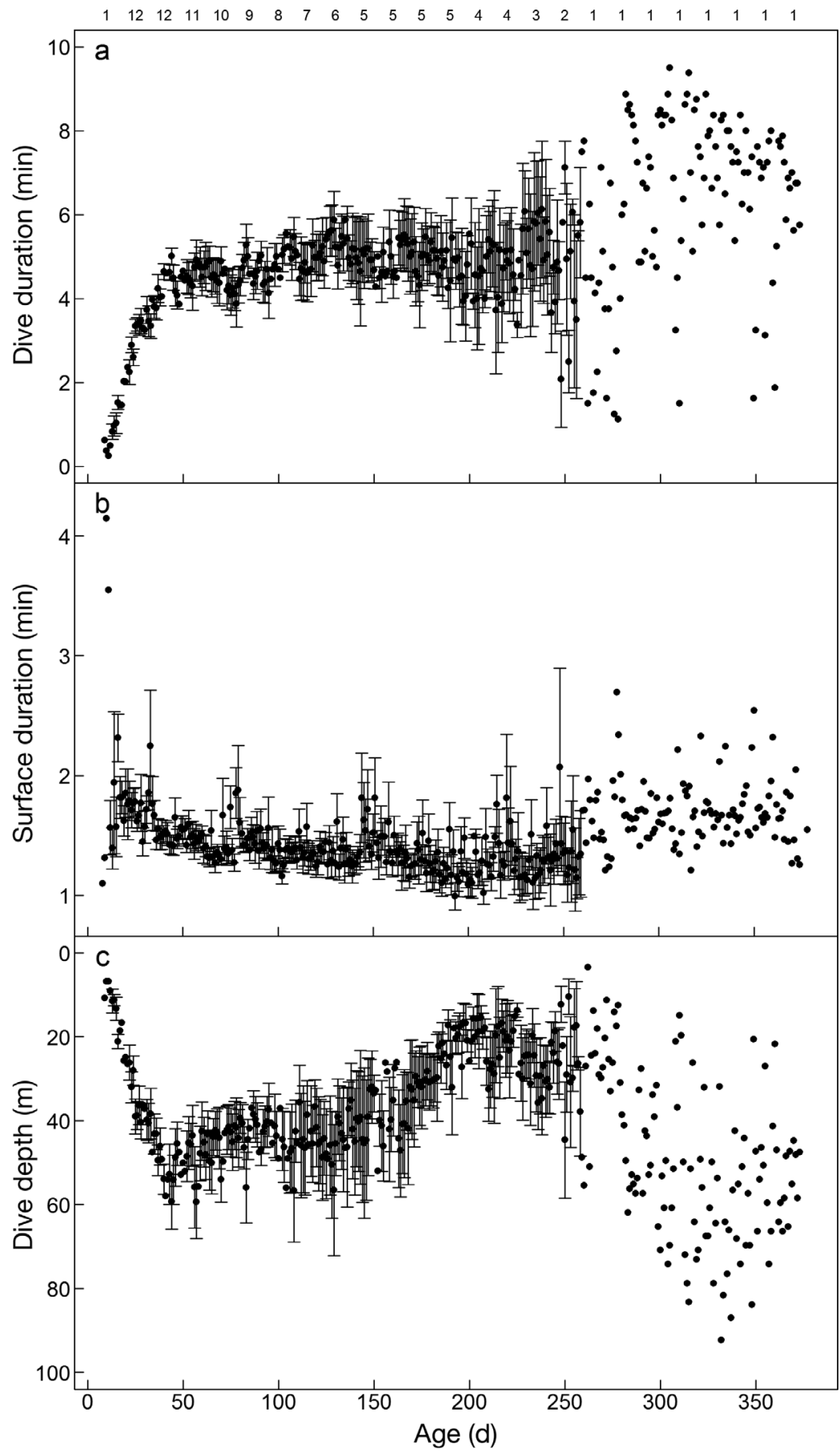

Fig. 7. Ontogenetic changes in (a) dive duration, (b) surface duration between dives and (c) dive depth over the first year of life for 13 bearded seal Erignathus barbatus pups. Data are mean $\pm \mathrm{SE}$; no error bars shown when only 1 pup was transmitting data. The number of pups transmitting data is shown above (a)

lower total body oxygen stores of pups compared to adults do not provide a large constraint due to the large size of bearded seal pups and the fact that they forage on shallow-dwelling benthos (infauna, epifauna and benthically distributed fishes; Lowry et al. 1980, Hjelset et al. 1999). Pups did dive to greater depths than adult bearded seals in Svalbard until they were $180 \mathrm{~d}$ old, when diving depths became shallower (this study, Hamilton et al. 2018). Pups likely dove to deeper depths than adults in an exploratory manner, before they learned that food is found at shallow depths. Pups may also be feeding on different prey than adults. In the Bering and Chukchi Sea region, young bearded seals eat fewer crabs and more shrimps and isopods than older bearded seals (Lowry et al. 1980). An alternative explanation for the differences in dive depth is competitive exclusion; Smith (1981) hypothesized that adult bearded seals exclude sub-adults from nearshore areas in the summer as an explanation for a dominance of adults caught in summer harvests.

Dive depth of pups decreased around 180 to $200 \mathrm{~d}$ of age, to depths comparable to mean diving depths of adult bearded seals in Svalbard (this study, Hamilton et al. 2018). Other dive parameters of bearded seal pups also changed at this time; bottom time decreased (bottom time is highly variable among adult bearded seals in Svalbard) and dive frequency increased (to a higher number of dives per day than adults) compared to earlier in the tracking period, while dive duration remained similar (at shorter durations compared to adults; Hamilton et al. 2018). Bottom time may have decreased for several reasons. Pups foraging skills may have increased to the point where they no longer needed to spend quite as much time searching on the bottom. Alternatively, pups could be targeting different prey types. The lower bottom time (i.e. after 180-200 d of age) performed by pups is similar to the bottom time of 3 of the 7 adult bearded seals tagged in Svalbard; 1 of these seals predominately did benthic dives, while the other 2 had a greater percentage (up to $49 \%$ ) of pelagic dives (Hamilton et al. 2018). The finding that bearded seal pups have a higher dive frequency (i.e. after 180-200 d of age) than adults is similar to the situation for many other pinniped species, and likely — as stated above — compensates for 


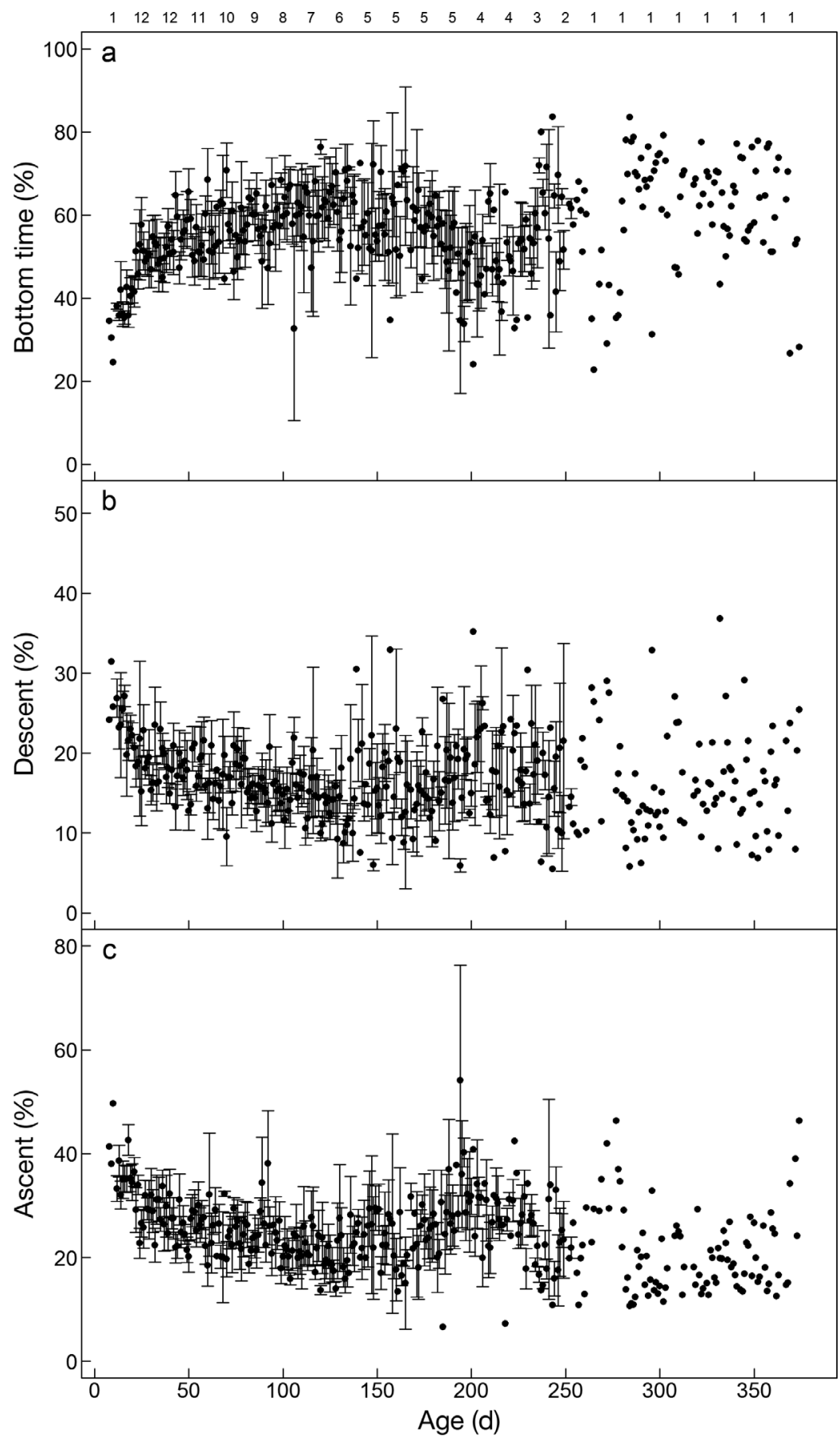

Fig. 8. Ontogenetic changes in (a) percentage of the dive at the bottom (depths $\geq 80 \%$ of the maximum diving depth), (b) in descent and (c) ascent over the first year of life for 13 bearded seal Erignathus barbatus pups. Data are mean $\pm \mathrm{SE}$; no error bars shown when only 1 pup was transmitting data. The number of pups transmitting data is shown above (a)

the shorter dives performed by young animals (Burns 1999, Fowler et al. 2006, Folkow et al. 2010). It is not clear why bearded seal pups did not compensate for shorter dive durations with a higher dive frequency at young ages.
The timing of some of the major changes in the dive parameters of the bearded seal pups in this study coincides with the onset of polar night (i.e. $24 \mathrm{~h}$ of darkness) in Svalbard. Bearded seals have extremely sensitive facial vibrissae, which aid in benthic foraging (Marshall et al. 2006). However, it is possible that light is still important for foraging, or alternatively that the onset of polar night affects the distribution of potential prey. Pups would have no previous experience with such changes, which might explain the onset of differences in dive frequency between the age groups. Diel patterns in pups' dive behaviour also disappeared at this time (and reappeared after the end of the polar night for the one pup still transmitting data), lending support to the hypothesis that the disappearance of light, or changes in the prey community, affect bearded seal pup foraging behaviour.

Adult bearded seals in Svalbard are quite specialized in their diving behaviour, habitat use and feeding habits, with large variability in these metrics between individuals (Hindell et al. 2012, Hamilton et al. 2018). However, bearded seal pups in the present study were found to have very homogeneous patterns of habitat use and diving behaviour. Young bearded seals in the Bering Sea were also similar in their selection of habitat variables (Cameron et al. 2018). This suggests that bearded seals in Svalbard do not become specialized in their habitat use and diving behaviour until after the period covered in the present study.

The environment and food web in Svalbard is currently changing in a manner that will likely affect bearded seal pup ontogeny and bearded seal ecology more generally (e.g. Bartsch et al. 2016, Pavlova et al. 2019). Landfast sea ice extent is declining rapidly in Svalbard, especially on the west coast (Laidre et al. 2015, Pavlova et al. 2019). Due to less ice scouring and a longer growing season, benthic biomass and productivity have increased in shallow parts of fjords in Svalbard (Bartsch et al. 2016). The distribu- 


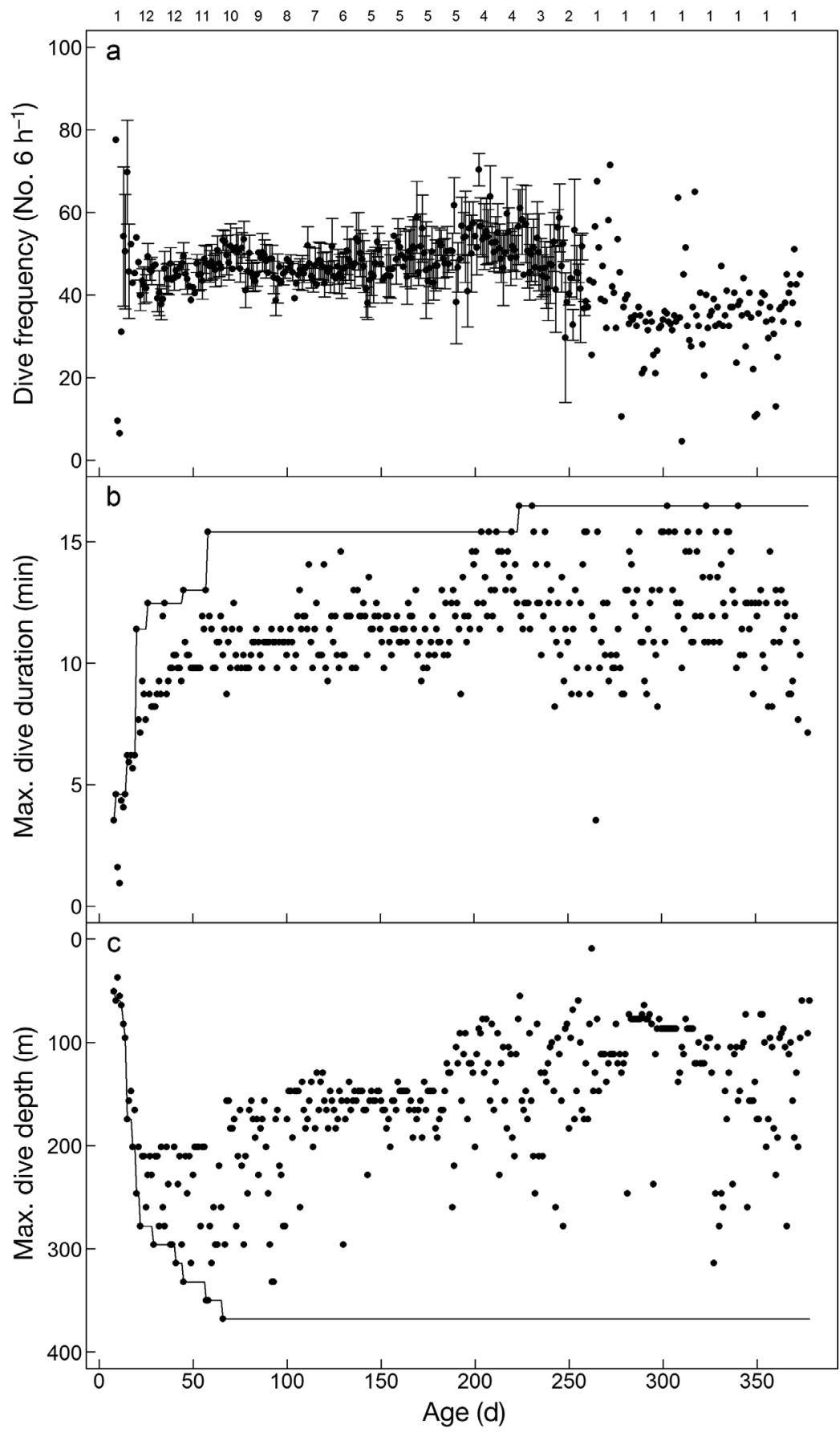

Fig. 9. Ontogenetic changes in (a) dive frequency (mean $\pm \mathrm{SE}$; no error bars shown when only 1 pup was transmitting data), (b) maximum dive duration and (c) maximum dive depth over the first year of life for 13 bearded seal Erignathus barbatus pups. The number of pups transmitting data is shown above (a). Solid lines in (b) and (c) show the maximum dive depth and duration obtained in the tracking record

tional area for bearded seals has also increased in the last decade as large expanses of land-fast ice in the winter and spring previously limited bearded seal access to inner-fjord areas during winter (Gjertz et al. 2000, Hamilton et al. 2018). Interannual variation in sea-ice extent has been shown to have consequences for adult bearded seal diet, with adults eating more pelagic fish and fewer benthic invertebrates in years with larger amounts of land-fast ice (Hindell et al. 2012). The ongoing decrease in land-fast ice in Svalbard will likely also influence the distribution, movements and diet of pups and positively influence pup foraging success. However, the ongoing declines in sea-ice extent and decreases in the number of tidal glacier fronts (Błaszczyk et al. 2009) will likely have a negative effect on bearded seal reproduction. Bearded seals do sometimes haul out on land in Svalbard (Merkel et al. 2013, K.M.K. and C.L. pers. obs.), as they do in other parts of their range, but neither birthing nor nursing have been documented in association with land for this species. In the longer term, Arctic ecosystems are expected to switch from sea-ice algal-benthos dominance to pelagic phytoplanktonzooplankton dominance (Piepenburg 2005), and this reduction in benthic biomass will likely have negative consequences for bearded seals, and affect the foraging ecology of bearded seals of all ages.

In summary, bearded seal pups are extremely precocial, and their activity and diving behaviour develop rapidly during the first few months of life. Behavioural patterns stabilize somewhat when pups are $\sim 50 \mathrm{~d}$ of age. However, ontogeny of diving behaviour was likely not complete even at the age of $1 \mathrm{yr}$, as pups did not develop the individually specialized diving behaviour documented for adult bearded seals in Svalbard (Hamilton et al. 2018). Further studies of bearded seal pups are needed to assess how pup ontogeny varies in Arctic regions with different habitats than Svalbard. Future research will also be needed to understand how bearded seals of all ages, including early developmental phases, are being affected by ongoing climate change. 
Acknowledgements. We thank Chris Marshall, Tray Wright and Yuuki Watanabe for help in the field. Funding was provided by the Norwegian Research Council (MARE programme, grant number 164940). C.D.H. was funded by the Norwegian Polar Institute's Centre for Ice, Climate and Ecosystems.

\section{LITERATURE CITED}

Andersen M, Hjelset AM, Gjertz I, Lydersen C, Gulliksen B (1999) Growth, age at sexual maturity and condition in bearded seals (Erignathus barbatus) from Svalbard, Norway. Polar Biol 21:179-185

* Bartsch I, Paar M, Fredriksen S, Schwanitz M, Daniel C, Hop $\mathrm{H}$, Wiencke C (2016) Changes in kelp forest biomass and depth distribution in Kongsfjorden, Svalbard, between 19961998 and 2012-2014 reflect Arctic warming. Polar Biol 39:2021-2036

Bennett KA, McConnell BJ, Moss SEW, Speakman JR, Pomeroy PP, Fedak MA (2010) Effects of age and body mass on development of diving capabilities of gray seal pups: costs and benefits of the postweaning fast. Physiol Biochem Zool 83:911-923

Blanchet MA, Lydersen C, Ims RA, Kovacs KM (2016) Making it through the first year: ontogeny of movement and diving behavior in harbor seals from Svalbard, Norway. Mar Mamm Sci 32:1340-1369

Błaszczyk M, Jania JA, Hagen JO (2009) Tidewater glaciers of Svalbard: recent changes and estimates of calving fluxes. Pol Polar Res 30:85-142

Bowen WD (1991) Behavioural ecology of pinniped neonates. In: Renouf D (ed) The behaviour of pinnipeds. Chapman \& Hall, London, p 66-127

Bowen WD (2018) Pinniped ecology. In: Würsig B, Thewissen JGM, Kovacs KM (eds) Encyclopedia of marine mammals, $3^{\text {rd }}$ Edn. Academic Press, San Diego, CA, p 705-712

Burns JJ (1970) Remarks on the distribution and natural history of pagophilic pinnipeds in the Bering and Chukchi Seas. J Mammal 51:445-454

Burns JM (1999) The development of diving behavior in juvenile Weddell seals: pushing physiological limits in order to survive. Can J Zool 77:737-747

Burns JJ, Frost KJ (1979) Natural history and ecology of the bearded seal, Erignathus barbatus. Final report to Outer Continental Shelf Environmental Assessment Program (OCSEAP), contract \#02-5-022-53. Alaska Department of Fish and Game, Fairbanks, AK

Burns JM, Clark CA, Richmond JP (2004) The impact of lactation strategy on physiological development of juvenile marine mammals: implications for the transition to independent foraging. Int Congr Ser 1275:341-350

Burns JM, Costa DP, Frost K, Harvey JT (2005) Development of body oxygen stores in harbor seals: effects of age, mass, and body composition. Physiol Biochem Zool 78:1057-1068

Cameron MF, Frost KJ, Ver Hoef JM, Breed GA, Whiting AV, Goodwin J, Boveng PL (2018) Habitat selection and seasonal movements of young bearded seals (Erignathus barbatus) in the Bering Sea. PLOS ONE 13:e0192743

Chapskii KK (1938) The bearded seal (Erignathus barbatus, Fabr.) of the Kara and Barents Seas. Can Fish Mar Serv Transl Ser No. 3162

Collecte Localisation Satellites (CLS) (2016) Argos user's manual. www.argos-system.org/manual/ (accessed 20 Feb 2018)
Comiso JC, Hall DK (2014) Climate trends in the Arctic as observed from space. Wiley Interdiscip Rev Clim Change 5:389-409

Crawford JA, Frost KJ, Quakenbush LT, Whiting A (2012) Different habitat use strategies by subadult and adult ringed seals (Phoca hispida) in the Bering and Chukchi seas. Polar Biol 35:241-255

Folkow LP, Nordøy ES, Blix AS (2010) Remarkable development of diving performance and migrations of hooded seals (Cystophora cristata) during their first year of life. Polar Biol 33:433-441

*Fowler SL, Costa DP, Arnould JPY, Gales NJ, Kuhn CE (2006) Ontogeny of diving behaviour in the Australian sea lion: trials of adolescence in a late bloomer. J Anim Ecol 75:358-367

Freitas C, Lydersen C, Fedak MA, Kovacs KM (2008) A simple new algorithm to filter marine mammal Argos locations. Mar Mamm Sci 24:315-325

Gjertz I, Kovacs KM, Lydersen C, Wiig Ø (2000) Movements and diving of bearded seal (Erignathus barbatus) mothers and pups during lactation and post-weaning. Polar Biol 23:559-566

*Hamilton CD, Lydersen C, Ims RA, Kovacs KM (2016) Coastal habitat use by ringed seals Pusa hispida following a regional sea-ice collapse: importance of glacial refugia in a changing Arctic. Mar Ecol Prog Ser 545: 261-277

*Hamilton CD, Kovacs KM, Lydersen C (2018) Individual variability in diving, movement and activity patterns of adult bearded seals in Svalbard, Norway. Sci Rep 8: 16988

*Hammill MO, Kovacs KM, Lydersen C (1994) Local movements by nursing bearded seal (Erignathus barbatus) pups in Kongsfjorden, Svalbard. Polar Biol 14:569-570

*Hauser DDW, Laidre KL, Suydam RS, Richard PR (2014) Population-specific home ranges and migration timing of Pacific Arctic beluga whales (Delphinapterus leucas). Polar Biol 37:1171-1183

*Hindell MA, Lydersen C, Hop H, Kovacs KM (2012) Prepartum diet of adult female bearded seals in years of contrasting ice conditions. PLOS ONE 7:e38307

*H Hjelset AM, Andersen M, Gjertz I, Lydersen C, Gulliksen B (1999) Feeding habits of bearded seals (Erignathus barbatus) from the Svalbard area, Norway. Polar Biol 21: 186-193

Holsvik R (1998) Maternal behaviour and early behavioural ontogeny of bearded seals (Erignathus barbatus) from Svalbard, Norway. MS thesis, Norwegian University of Science and Technology (NTNU), Trondheim

* Jakobsson M, Mayer L, Coakley B, Dowdeswell JA and others (2012) The International Bathymetric Chart of the Arctic Ocean (IBCAO) Version 3.0. Geophys Res Lett 39: L12609

Johnson DS, London JM, Lea MA, Durban JW (2008) Continuous-time correlated random walk model for animal telemetry data. Ecology 89:1208-1215

Jørgensen C, Lydersen C, Brix O, Kovacs KM (2001) Diving development in nursing harbor seal pups. J Exp Biol 204: 3993-4004

König M, Kohler J, Nuth C (2013) Glacier area outlines Svalbard. Norwegian Polar Institute, Tromsø, doi: 10.21334/npolar.2013.89f430f8

Kovacs KM (1987a) Maternal behaviour and early behavioural ontogeny of harp seals, Phoca groenlandica. Anim Behav 35:844-855 
Kovacs KM (1987b) Maternal behaviour and early behavioural ontogeny of grey seals (Halichoerus grypus) on the Isle of May, UK J Zool (Lond) 213:697-715

Kovacs KM (2018) Bearded seal. In: Würsig B, Thewissen JGM, Kovacs KM (eds) Encyclopedia of marine mammals, $3^{\text {rd }}$ Edn. Academic Press, San Diego, CA, p 83-86

Kovacs KM, Lavigne DM (1986) Maternal investment and neonatal growth in phocid seals. J Anim Ecol 55: 1035-1051

Kovacs KM, Lavigne DM (1992) Mass-transfer efficiency between hooded seal (Cystophora cristata) mothers and their pups in the Gulf of St. Lawrence. Can J Zool 70: 1315-1320

Kovacs KM, Lydersen C, Gjertz I (1996) Birth-site characteristics and prenatal molting in bearded seals (Erignathus barbatus). J Mammal 77:1085-1091

Krafft BA, Lydersen C, Kovacs KM, Gjertz I, Haug T (2000) Diving behaviour of lactating bearded seals (Erignathus barbatus) in the Svalbard area. Can J Zool 78:1408-1418

Kranstauber B, Kays R, LaPoint SD, Wikelski M, Safi K (2012) A dynamic Brownian bridge movement model to estimate utilization distributions for heterogeneous animal movement. J Anim Ecol 81:738-746

Laidre KL, Stern H, Kovacs KM, Lowry L and others (2015) Arctic marine mammal population status, sea ice habitat loss, and conservation recommendations for the $21^{\text {st }}$ century. Conserv Biol 29:724-737

Lowry LF, Frost KJ, Burns JJ (1980) Feeding of bearded seals in the Bering and Chukchi Seas and trophic interaction with Pacific walruses. Arctic 33:330-342

Lydersen C (2018) Walrus. In: Würsig B, Thewissen JGM, Kovacs KM (eds) Encyclopedia of marine mammals, $3^{\text {rd }}$ Edn. Academic Press, San Diego, CA, p 1045-1048

Lydersen C, Kovacs KM (1999) Behaviour and energetics of ice-breeding, North Atlantic phocid seals during the lactation period. Mar Ecol Prog Ser 187:265-281

* Lydersen C, Hammill MO, Kovacs KM (1994) Diving activity in nursing bearded seal (Erignathus barbatus) pups. Can J Zool 72:96-103

Lydersen C, Kovacs KM, Hammill MO, Gjertz I (1996) Energy intake and utilisation by nursing bearded seal (Erignathus barbatus) pups from Svalbard, Norway. J Comp Physiol B 166:405-411

Lydersen C, Kovacs KM, Ries S, Knauth M (2002) Precocial diving and patent foramen ovale in bearded seal (Erignathus barbatus) pups. J Comp Physiol B 172:713-717

Lydersen C, Assmy P, Falk-Petersen S, Kohler J and others (2014) The importance of tidewater glaciers for marine mammals and seabirds in Svalbard, Norway. J Mar Syst 129:452-471

Mann J (2018) Parental behavior. In: Würsig B, Thewissen JGM, Kovacs KM (eds) Encyclopedia of marine mammals, $3^{\text {rd }}$ edn. Academic Press, San Diego, CA, p 686-691

Marshall CD, Amin H, Kovacs KM, Lydersen C (2006) Microstructure and innervation of the mystacial vibrissal follicle-sinus complex in bearded seals, Erignathus barbatus (Pinnipedia: Phocidae). Anat Rec A Discov Mol Cell Evol Biol 288A:13-25

McLaren IA (1958) Some aspects of growth and reproduction of the bearded seal, Erignathus barbatus (Erxleben). J Fish Res Board Can 15:219-227

Editorial responsibility: Robert M. Suryan,

Juneau, Alaska, USA
Merkel B, Lydersen C, Yoccoz NG, Kovacs KM (2013) The world's northernmost harbour seal population-How many are there? PLOS ONE 8:e67576

Pavlova O, Gerland S, Hop H (2019) Changes in sea-ice extent and thickness in Kongsfjorden, Svalbard (20032016). In: Hop H, Wiencke $C$ (eds) The ecosystem of Kongsfjorden, Svalbard. Advances in polar ecology, Vol 2. Springer, Cham, p 105-136 (in press)

*Piepenburg D (2005) Recent research on Arctic benthos: common notions need to be revised. Polar Biol 28: 733-755

Pinheiro J, Bates D, DebRoy S, Sarkar D, R Core Team (2017) nlme: linear and nonlinear mixed effects models. R package version 3.1-131. https:/CRAN.R-project.org/ package $=$ nlme

* Pitcher K, Rehberg MJ, Pendleton GW, Raum-Suryan KL, Gelatt TS, Swain UG, Sigler MF (2005) Ontogeny of dive performance in pups and juvenile Steller sea lions in Alaska. Can J Zool 83:1214-1231

R Core Team (2017) R: a language and environment for statistical computing. R Foundation for Statistical Computing, Vienna, www.r-project.org

Raum-Suryan KL, Rehberg MJ, Pendleton GW, Pitcher KW, Gelatt TS (2004) Development of dispersal, movement patterns, and haul-out use by pup and juvenile Steller sea lions (Eumetopias jubatus) in Alaska. Mar Mamm Sci 20:823-850

Simpkins MA, Hiruki-Raring LM, Sheffield G, Grebmeier JM, Bengston JL (2003) Habitat selection by ice-associated pinnipeds near St. Lawrence Island, Alaska in March 2001. Polar Biol 26:577-586

Smith TG (1981) Notes on the bearded seal, Erignathus barbatus, in the Canadian Arctic. Can Tech Rep Fish Aquat Sci 1042:1-55

* Stewart BS (1997) Ontogeny of differential migration and sexual segregation in northern elephant seals. J Mammal 78:1101-1116

Sumner MD (2016) trip: tools for the analysis of animal track data. R package version 1.5.0. https://CRAN.R-project. org/package=trip

Vacquie-Garcia J, Lydersen C, Biuw M, Haug T, Fedak MA, Kovacs KM (2017) Hooded seal Cystophora cristata foraging areas in the Northeast Atlantic Ocean-investigated using three complementary methods. PLOS ONE 12:e0187889

*Vacquié-Garcia J, Lydersen C, Ims RA, Kovacs KM (2018) Habitats and movement patterns of white whales Delphinapterus leucas in Svalbard, Norway in a changing climate. Mov Ecol 6:21

*Watanabe Y, Lydersen C, Sato K, Naito Y, Miyazaki N, Kovacs KM (2009) Diving behaviour and swimming style of nursing bearded seal pups. Mar Ecol Prog Ser 380: $287-294$

*Wolff JO (1994) More on juvenile dispersal in mammals. Oikos 71:349-352

Wood SN (2006) Generalized additive models: an introduction with R. Chapman \& Hall/CRC Press, Boca Raton, FL

Zuur AF, Ieno EN, Walker NJ, Saveliev AA, Smith GM (2009) Mixed effects models and extensions in ecology with R. Springer, New York, NY

Submitted: March 13, 2019; Accepted: July 11, 2019

Proofs received from author(s): September 16, 2019 